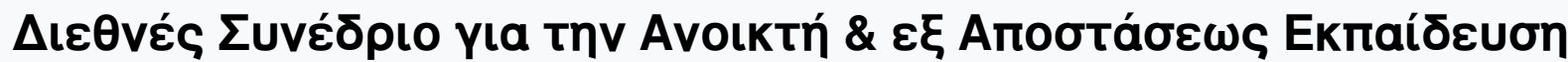

Tó. 5, Ap. 3B (2009)

Open and Distance Education for Global Collaboration \& Educational Development

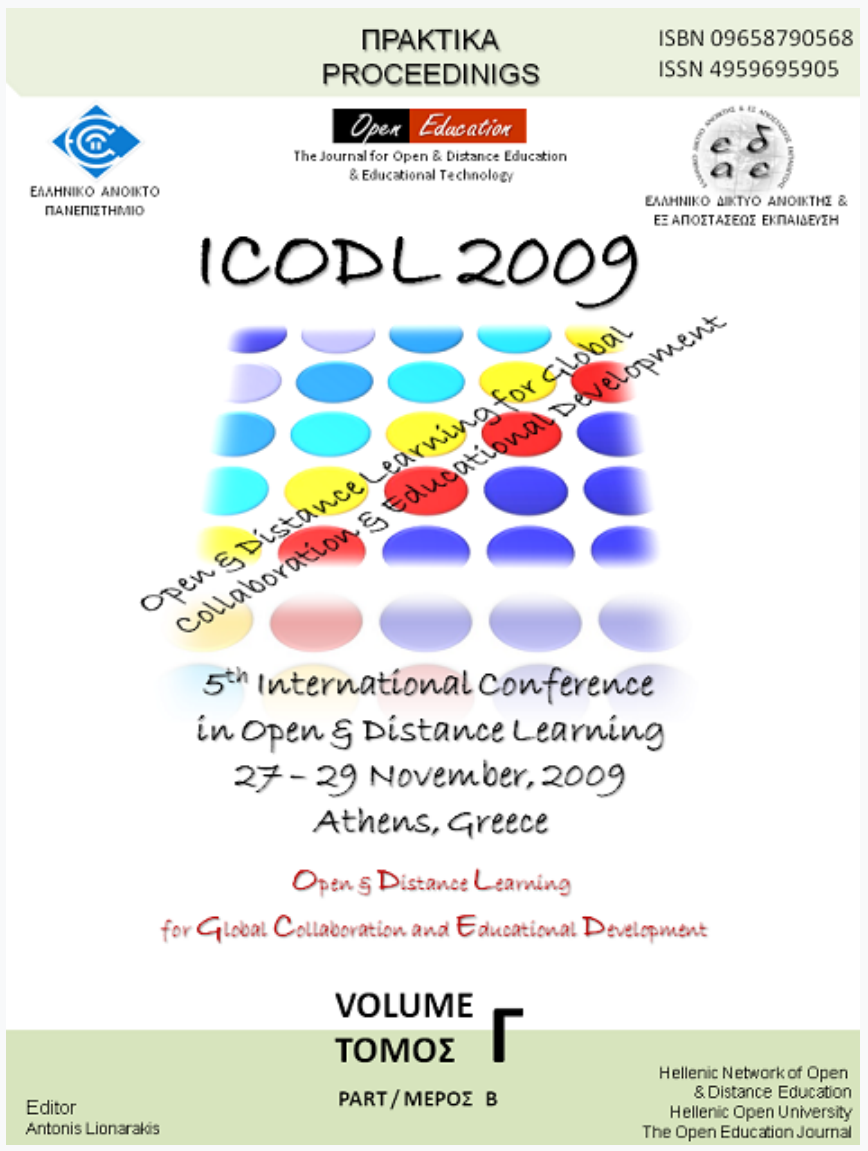

Fields of changes in the Polish vocational education system. Capabilities for distance vocational education

Aleksandra KULPA-PUCZYNSKA

doi: $10.12681 /$ icodl. 474 


\title{
Fields of changes in the Polish vocational education system. Capabilities for distance vocational education
}

\author{
Aleksandra KULPA-PUCZYNSKA \\ MA, academic teacher, assistant \\ Kazimierz Wielki University in Bydgoszcz (Poland), Faculty of Pedagogy and Psychology, \\ Institute of Pedagogy, Department of Pedagogics of Work and Andragogic \\ olakulpa@ukw.edu.pl
}

\begin{abstract}
The aim of this article is to 1) show transformations and conditionings in the field of vocational education in Poland and 2) calling attention to special role of distance education which is demonstrated in realization of educational needs, as well as on education capabilities, which are created by new technologies.

In this paper is underlined, that the Polish vocational education system spares no efforts on adaptation to the existing conditions so that vocational school graduates could have better prospects for employment, and later meet their vocational obligations. Hence, transformations in the field of vocational education (structural, organisational and program) were also to be made in accordance with the following principles: high quality education based on the system of standards; education flexibility, and vocational mobility. In the second part of the article touch upon a question of distance vocational education. The program offer, program surrounding, distance vocational education (development and implementation of the distance education system), and building a system of Internet education-vocational information and an active Internet system of education-vocational counselling - these are important problem fields and directions for actions the National Education Ministry.
\end{abstract}

\section{Introduction}

The issue of vocational education in Poland is the subject of many publications (B. Baraniak, A. Bogaj, H. Bednarczyk, W. Furmanek, R. Gerlach, U. Jeruszka, S. M. Kwiatkowski, F. Szlosek, Z. Wiatrowski and others), documents, conferences and scientific seminars. Polish literature on this subject stresses, among others, that vocational education of both school youth and further education (school and extraschool) of adults cannot be reduced exclusively to the instrumental sphere, i.e. to providing a person only with specific information, skills and vocational habits. The imperative objective of education, including vocational education, is uncovering and showing the entire person's potential. The more so that many professions require today abundant intellectual, moral and aesthetic education (Gerlach, 2003:174). It is considered nowadays that in the changing job market situations the individual's personality plays a special role, especially his or her ability of self-development. The attitudes, skills and knowledge that are conducive to time flexibility of a person to be employed, his or her adaptability and susceptibility to change are becoming more and more important. That's why the desired features of the contemporary employee and the ideal graduate at the same time are, among others: 
enterprise, initiative, ability of making independent analyses, co-operation and organisation of own work (Wiatrowski, 2005: 108).

Modern economy, globalisation and influence of high technologies on, for example, employment forms and work organisation create the demand for new qualifications and professional competence, and force Polish employees to complete or extend their qualifications. The job market being transformed causes also the necessity of frequent career change. Taking into account at least the above-named trends, the Polish vocational education system spares no efforts on adaptation to the existing conditions and needs so that vocational school graduates could have better prospects for employment, and later meet their (Jeruszka, 2002)

\section{Vocational education in Poland - reality and challenges}

According to the guidelines of the vocational education system reform started in 1999, school education of young people was to lead not only to gaining first vocational qualifications, but it also was to prepare to further education, constant education supplementation and improvement, and retraining if necessary. Hence, the guidelines of the vocational education system reform in Poland were aimed at two objectives, very significant to the changes mentioned earlier:

- vocational mobility, i.e. ability of frequent and quick change of the occupation, which is possible thanks to the right "base" preparation gained in school, on which one will be able to build specialist qualifications;

- vocational activity, i.e. looking for a job in other companies and selfemployment; as regards development of the ability of creating jobs and running a business - the point was also the conviction about one's own vocational value, and development of the ability to present oneself and one's work (Wiatrowski, 2000: 244).

Transformations in the field of vocational education (structural, organisational and program) were also to be made in accordance with the following principles: 1) high quality education based on the system of standards; 2) education flexibility, and 3) mobility mentioned above. Thus, development of a common model regarding the collection of skills and attitudes showing the employee's efficiency, effectiveness and responsibility turned out to be necessary. Vocational education had to be organised so that skilled employees could deepen and broaden their knowledge. Owing to this, they would not be limited to one position classified during school education, but in accordance with the mobility principle they would be able to do their job in similar positions in different places at different times (Bogaj, 2000). Whereas flexible reaction to the requirements of the contemporary job market was to assure:

- assimilation of vocational education with general and general-vocational education

- introduction of broad-profile professions and integrated subjects;

- change of character and range of participation of plants in vocational education processes;

- creation of an information and vocational counselling system in vocational schools; 
- re-evaluation in the field of vocational education objectives, content and methods

(Furmanek, 2005: 72).

The main purpose of the changes made was to provide a potential employer with supra-vocational and general vocational knowledge in a given economic sector, vocational skills connected with the future job and necessary technologies, as well as the right personality dispositions (Furmanek, 2006: 185). In accordance with these guidelines, at present the following undertakings play a important role in the adaptation of the Polish education system to the current and anticipated market needs:

- implementation of issues concerning the economic life and entrepreneurship within the subject "Basic entrepreneurship" (and introduction of programs teaching enterprising attitudes with the use of the active method into schools). The role of this subject is support for comprehensive development of the young generation, including building behaviour that determines active and conscious participation in the economic life;

- introduction of a vocational information and counselling system into vocational schools to help students make the right choice: education path or place of employment. Support for the Intra-school Counselling System (managed by a specialist in career preferences and counselling) by organised co-operation of teachers, parents and the local community;

- establishment of School Career Centres with the support of external surrounding (employment agencies, education and work centres OHP, entrepreneurs). The main objective of SCCs is to provide young people with knowledge and skills that will allow them to plan their professional career and to be able to meet the requirements of the contemporary job market, and first of all to function on the job market actively for many years;

- participation of Polish vocational schools in EU programs, for example Leonardo da Vinci, which aims at promotion of operations conducive to elimination of the gap between education and the job market needs. The project supports, among others, mobility of students and teachers of vocational schools, offering them international exchange and internships.

One cannot forget that the authors of the Polish education system reform adopted - as one of the strategic objectives - limitation of vocational education only to $20 \%$ of secondary education. It turned out to be very unfavourable due to the fact, among others, that the developing Polish economy had expected (and it still needs) first of all vocational school graduates. They are also sought after on the European job market (Kwiatkowski, 2007: 85). There is yet another problem. The qualifications of employees do not correspond with the current needs of employers, and this problem is getting deeper. The lack of adequately prepared people to work and the high non-pay work costs are the main problems

of Polish employers.

In order to minimise the results of the current vocational education marginalization and its unadjustedness to the job market requirements, development of solutions for the repair of this situation has been started. Taking into account various opinions in this field, one can indicate the following, proposed solutions: 1) connection in a definitely higher extent of vocational schools with the broadly understood sphere of economy (higher participation of employers in the creation of program foundations, organisation of training, preparation of examinations confirming vocational qualifications, personnel exchange: internships in enterprises 
for teachers and participation of economic practitioners, e.g. production and service specialists, in school education); 2) more visible integration between the school and extraschool vocational education system (introduction solutions used in the extraschool system into the school system: modular structure programs, vocational courses, vertical and horizontal patency between individual forms of school and extraschool vocational education); 3) increase in effectiveness of practical education provided at school workshops, practical education centres, plants and handicraft workshops; 4) attaching greater importance to language education in vocational schools (conducting classes in basic vocational subjects in foreign languages, popularisation of international student exchange, organisation of common examinations with schools from EU states, and acknowledgement of qualifications); 5) popularisation of vocational qualifications standards and their transformation into standards of examination requirements in the entire vocational education cycle; 6) legal regulation of requirements connected with education supplementation and improvement of vocational school teachers: cyclic training periods, domestic and foreign internships; $\quad$ 7) co-financing of projects and diploma theses by enterprises interested in their implementation, transfer of practical knowledge, research and innovations into vocational schools (Kwiatkowski, 2007: 86; Gerlach, 2006: 116).

\section{Distance vocational education}

Keeping in mind the quickest possible implementation of the above-named operations, among others, on the initiative of the National Education Ministry, the Consultative group for vocational education has been established. The group gathers representatives of individual ministries, employers' organisations, social partners, representatives of local government, education and scientific communities. Until February 2009, three meetings of this group were held to discuss such issues as:

- guidelines for modernisation of school professions classification and separation of qualifications, and profile of a vocational school graduate;

- career consultancy in the education system;

- system of examinations confirming qualifications in a profession;

- structure and organisation of vocational education;

- vocational education of people with special needs.

The consultative group is today the main constructor of changes in the Polish vocational and continuous education system, but its work is also supported by adequate expert opinions and research results, as well as opinions and propositions of representative communities. One of the elements of the planned vocational education "reform" is transition into the modular system assessed as an effective way of dealing with dynamic changes in work content. The National Education Ministry also wants to support projects aimed at establishing professional centres for practical education and modernisation of the vocational schools didactic base, and to promote the good practice of co-operation between employers and vocational schools. These are only some examples of increasing the attractiveness of education in vocational schools, besides the already used point thresholds to high schools and secondary vocational schools by local governments (Symela, 2009). 
New education possibilities are also created by new technologies. In Poland, just like in other EU states, they support the traditional forms and methods of vocational education, and are an alternative to the vocational education supplementation and improvement forms popular so far. E-learning is used in a different range, from making one multimedia training program on a $\mathrm{CD}$ available to implementation of a comprehensive education platform that combined the advantages of interactive education programs with

a possibility of direct contacts between student and teacher (Siemińska, 2006: 105). The selection and attractiveness of used means depends first of all on organisational and financial capabilities of a given school (especially in case of vocational education) or enterprises that apply such an education strategy. Due to these reasons, among others, The conception of implementation of the distance education system in Polish conditions" is one of the significant documents on the issues of continuous education. This is one of the priority operations mentioned in "The strategy for continuous education development until the year 2010". Though the results of research (Czapiński, 2006) show that the development of modern technologies has been improved in Poland over the last years (the percentage of people using a computer and the Internet on a regular basis and the computer skills of Poles have increased as well), there is still much to do in this field. A significant support from EU funds makes opportunities for development in this field possible.

Currently, many Polish schools undertake actions aimed at implementation of online education into study programs (e.g. by the AGH University of Science and Technology, Warsaw University of Technology, Wyższa Szkoła Biznesu - NationalLouis University in Nowy Sącz) and all type courses (mostly, these are only courses in some subjects). Internet postgraduate studies are also conducted (e.g. by the Warsaw University). There are also possibilities for education supplementation in post-secondary vocational schools, mainly in the field of administration, trade, tourism management, accounting and advertising. As regards online courses, these are most frequently language courses, but also courses connected with, e.g., banking, advertising and psychology, entrepreneurship, and management. The Polish Virtual University and the European Internet Academy are also active. So far, the academy has trained over 20,000 people in the field of knowledge on the EU and issued appropriate certificates for them (Podoska, 2006).

The program offer, program surrounding, distance vocational education (development and implementation of the distance education system), and building a system of Internet education-vocational information and an active Internet system of education-vocational counselling - these are next problem fields and directions for actions distinguished by the above-named consultative group for the vocational and continuous education reform. It is noteworthy here that organisational-program changes will be implemented gradually. First program changes concerning the first class of basic vocational schools and secondary technical schools will take place in the school year 2012/2013 (MEN, 2009).

It has to be remembered that the special role of distance education is manifested in satisfaction of education needs of the people, who - due to professional work specificity (e.g. flexible working hours) - have hampered access to organised trainings and live far away from education institutions, or it is difficult for them to make use of stationary education due to health or family problems. Thanks to the heyday of social communication techniques, they study while physically being in different places and/or in different time zones (Stochmiałek, 2002). Besides, 
Information and Communication Technology skills are becoming more and more significant to getting and keeping a job. That's the reason of drawing attention in Poland to the increasing need of investments in new basic skills: quick learning, effective communication, and active foreign language knowledge. In accordance with the recommendation of the European Parliament and Council (10.11.2005 COM (2005) 548), computer skills were recognised as key competence in life long learning. The role of education in economy based on knowledge was noticed earlier (2001), setting the strategic and detailed objectives (e.g. providing mass access to information-communication technologies) of education:

- improvement of the quality and effectiveness of education systems in the EU;

- facilitation of public access to education systems, and

- opening of education systems to the community and the world.(Gerlach, 2008: 232).

\section{Final reflection}

Summing up the reflections presented here, it has to be added that that the changes in the field of vocational education in Poland are conditioned to a significant extent also on structural transformations in economy and their importance to the job market, as well as on processes connected with European integration (Kwiatkowski, 2001: 15). A characteristic feature of developing economies, such as the Polish economy, is the fact that they increase the demand on highly qualified employees, whose supply in Poland turns out insufficient today. The reason for such a status quo is the fact that rising markets (including Polish market) experience the loss of "talents" caused by looking for jobs in the Euro zone by employees.

Among the trends having an influence on the dynamics of changes on the job market after Poland's accession to the EU, and as a consequence on the organisation and process of vocational education, the following factors should be stressed as well: demand on new professions and qualifications (especially in the field of new technologies); growing scale of seasonal increase in the number of working people; greater importance of periodic employment and advantage of increase in productivity over pay pressure (Pomianek, 2005) Besides, the European context of transformations in vocational education results also from the effects of projects of the European Social Fund, objectives of the renewed Lisbon Strategy, implementation of the strategy of life long learning (LLL), domestic and European qualification frameworks, and instruments improving the quality of vocational and continuous education (ECVET, EQARF, EUROPASS) (Symela, 2009). Implementation of the "new" vocational education functions should thus be aimed at both vocational preparation, autocreation, development of values and pro-democratic attitudes, and shaping of vocational mobility, as well as preparation to life and work in multicultural communities (Kwiatkowski, 2002: 15). 


\section{Bibliography}

Bogaj, A. (2000). Kształcenie zawodowe w świetle międzynarodowych raportów oświatowych priorytety i kierunki rozwoju, [in:] Kształcenie zawodowe. Rynek pracy. Pracodawcy, edited by S. M. Kwiatkowski, Warsow, p. 37-38.

Czapiński, J., Panek, T. (eds). (2006). Diagnoza Społeczna 2005. Warunki i jakość życia Polaków, Rada Monitoringu Społecznego, Wyższa Szkoła Finansów i Zarządzania, Warsaw.

Furmanek, W. (2005). Ewolucja zawodów istotnym problemem teorii edukacji zawodowej, „Pedagogika Pracy”, nr 46, p.72.

Furmanek, W. (2006). Zarys humanistycznej teorii pracy (nowe horyzonty pedagogiki pracy), Warsaw, p.185-186 and 375.

Gerlach, R. (2003). Edukacja zawodowa nie tylko dla rynku pracy, [in:] Edukacja wobec rynku pracy. Realia - możliwości - perspektywy, edited by R. Gerlach, Bydgoszcz, p.174-175.

Gerlach, R. (2006). Nowe obszary badań w pedagogice pracy, [in:] Pedagogika pracy i andragogika w konstelacji europejskiej i globalnej, edited by Z. Wiatrowski, Włocławek, p.116-118.

Gerlach, R. (2008). Edukacja zawodowa w aspekcie „końca pracy”, [in:] Edukacja i praca. Konteksty wyzwania - antynomie, edited by R. Gerlach, Bydgoszcz, p. 232.

Jeruszka, U. (2002). Kształcenie zawodowe wobec integracji z Unią Europejską, [in:] Kształcenie prozawodowe i zawodowe w kontekście integracji Europy, edited by R. Gerlach, Bydgoszcz, p.159.

Kwiatkowski, S.M. (2001). Kształcenie zawodowe. Dylematy teorii i praktyki, Warsaw, p. 15.

Kwiatkowski, S.M. (2002). Dziś i jutro kształcenia zawodowego, „Nowa Edukacja Zawodowa”, nr 5, p.12.

Kwiatkowski, S.M. (2007). Kształcenie zawodowe w systemie szkolnym jako droga do dorosłości, [in:] Pedagogika pracy i andragogika z myślą o dorastaniu, dorosłości i starości człowieka w XXI wieku, edited by Z. Wiatrowski, K. Ciżkowicz, Włocławek, p.85-87.

Ministry of Education (Department of Vocational and Permanent Education), Ministry of Education current works on the reform of vocational education in Poland, III Education Fair, Education Research - Innovation "Vocational education in response to the challenges of modern times", Poznań 14.03. 2009r.

Podoska - Filipowicz, E., Michalski, A. (2006). Edukacja ustawiczna online, [w:] Pedagogika pracy i andragogika w konstelacji europejskiej i globalnej, edited by Z. Wiatrowski, Włocławek, p.319.

Pomianek, T., Rozmus, A., Przywara, B., Bienia, M., Czyżewska, M. (2005). Raport Rynek pracy w Polsce i Unii Europejskiej, wydanie IV, poszerzone i uaktualnione, Rzeszów, p.22.

Siemińska - Łosko, A. (2006). Rola portali edukacyjnych w procesie e-learningu, [in:] Kształcenie na odległość w świetle badań i analiz, edited by B. Siemieniecki, Toruń, p.105-107.

Stochmiałek, J. (2002). Kształcenie otwarte i kształcenie na odległość w procesie globalizacji, Edukacja Ustawiczna Dorosłych", nr 3, p. 39-40.

Symela, K. (2009). O reformie kształcenia zawodowego, Portal wiedzy o edukacji.

Retrieved on 5 June, 2009 from http://www.gazeta.edu.pl/O reformie_kształcenia zawodowego95 577-0.html

Wiatrowski, Z. (2000). Podstawy pedagogiki pracy, Bydgoszcz, p. 244.

Wiatrowski, Z. (2005). Podstawy pedagogiki pracy, Bydgoszcz, p.108-109. 